\title{
The availability of lysine in groundnut biscuits used in the treatment of kwashiorkor. $2 *$
}

\author{
BY K. J. CARPENTER AND BERYL E. MARCH† \\ School of Agriculture, University of Cambridge \\ (Received 5 December I960-Revised 6 February 196I)
}

Clegg (1960) has reported an analytical study on a type of biscuit containing groundnuts and skim milk as the main sources of protein and intended as a dietary supplement in the treatment of kwashiorkor. Clinical results had, however, indicated the biscuits to be of somewhat inferior nutritive quality. Clegg found that there was significantly less 'available lysine' in these biscuits than in an unbaked mixture of the same ingredients.

The chemical procedure (Bruno \& Carpenter, 1957) was to measure those lysine residues in the protein of the biscuit that had their $\epsilon$-amino groups free to act with fluorodinitrobenzene. There is considerable indirect evidence that only those residues that remain reactive after the processing of a food are nutritionally available; but there have been no direct biological tests with this particular material.

In the study reported here the loss of available lysine upon cooking has been determined by chemical analysis and by biological assays on chicks.

\section{EXPERIMENTAL}

\section{Composition and preparation of biscuits}

The procedure for preparation of the biscuits approximated to that of Clegg (1960) for her biscuits ${ }_{5} \mathrm{C}$ and ${ }_{15} \mathrm{U}$. The ingredients differed from hers in that whole-maize meal was used in place of $70 \%$ extraction maize flour and arachis oil was substituted for cottonseed oil. The percentage composition of the biscuits was: groundnuts $4 \mathrm{I}$, maize meal 20, white wheaten flour 6 , sucrose 12 , arachis oil 6 and skim-milk powder 15 .

Batches of $4 \mathrm{~kg}$ of the material were prepared for each baking. For the (C) biscuit all the ingredients were blended in an electric mixer, $467 \mathrm{ml}$ of water were introduced gradually and the dough was then rolled out to a thickness of approximately $\mathrm{I} \mathrm{cm}$ and cut in strips. These strips were baked for $20-25 \mathrm{~min}$ on aluminium foil on perforated metal trays in an oven kept within $180-200^{\circ}$. The baked biscuit was of a light-brown colour. A few minutes after removal from the oven the strips were broken up and left overnight to harden before being ground in a hammer-mill.

The (U) biscuit was prepared similarly, except that the skim-milk powder and

* Paper no. I: Brit. F. Nutr. (1960), 14, 325.

$\uparrow$ Present address: Department of Poultry Science, University of British Columbia, Vancouver. 
one-half the oil were withheld from the mix until after the biscuit had been baked and milled.

Neither biscuit meal had any burnt flavour and both appeared to have been cooked in such a way as to give a palatable product. The final biscuit meals (U) and (C) contained 3.5 and $6.5 \%$ moisture and 19.2 and $18.7 \%$ crude protein, respectively. They were stored at room temperature for $3^{-6}$ days before being mixed into the experimental diets.

\section{Microbiological and chemical assays}

Analyses for the total lysine content of the biscuits were carried out for us by a commercial laboratory (H. Pritchard, I3/14 Hamilton Square, Birkenhead, Cheshire). The samples were first acid-hydrolysed and then assayed for their lysine content with Leuconostoc mesenteroides P. 60.

The $\epsilon$-amino groups free to react with fluorodinitrobenzene were determined by two slightly different procedures. Procedure A (Bruno \& Carpenter, 1957) was that used by Clegg ( 1960 ) in her study, but is now known to need correction for two sources of error acting in opposite directions: loss of dinitrophenyllysine (DNPL) during acid hydrolysis and presence of interfering colour from a histidine derivative. A correction can be made for the former by using DNPL added just before the acidhydrolysis stage, as an internal standard. Correction for the presence of a histidine derivative can be made by reading the extinction of the final solution at two wavelengths (Carpenter, Jones \& Mason, 1959). Procedure B (Carpenter, I960) avoids interference from histidine derivatives, but it has been studied so far only for use with animal products; with these the loss of DNPL at the hydrolysis stage has been about $8 \%$, but a separate measure was needed for the carbohydrate-containing materials examined in this study.

\section{Biological assay}

A group of 175 newly hatched cockerel chicks (White Leghorn $\times$ Rhode Island Red) was fed on a commercial ration for 3 days and then transferred for a further 7 days to a diet suboptimal in lysine but otherwise of good quality (Carpenter \& March, 196r, unpublished).

The population was then reduced to 108 by discarding the slowest- and the fastestgrowing birds. The remaining chicks were distributed into thirty-six groups of three each by the following procedure. First the eighteen heaviest chicks were randomized into one stratum of six cages, then the eighteen next heaviest chicks were randomized into the second stratum, and so on for six strata. Each of the six experimental diets was then allotted to one group in each stratum.

The chicks were housed by grouping in small cages with raised wire floors. The experimental diet was provided ad lib. in a dry, ground form. Water was also supplied ad lib. The experimental diets were given for 9 days, and records were kept of each chick's gain in weight. Two separate estimations of the feed consumption with each dietary treatment were made by measuring the total consumptions of the three heaviest groups and of the three remaining groups for each diet.

The compositions of the experimental diets are given in Table 1 . They were 
formulated to contain $26 \%$ protein. It was calculated that all the diets would be primarily deficient in lysine unless specially supplemented with it. The diets containing the (C) biscuit were supplemented with different levels of lysine to determine the amount required to promote a rate of growth similar to that obtained with the (U) biscuit, and thus an estimate of the difference in the 'available lysine' content of the two biscuits was made.

Table 1. Percentage composition of the diets used in the chick assay, and mean gain in weight and feed consumption of the chicks

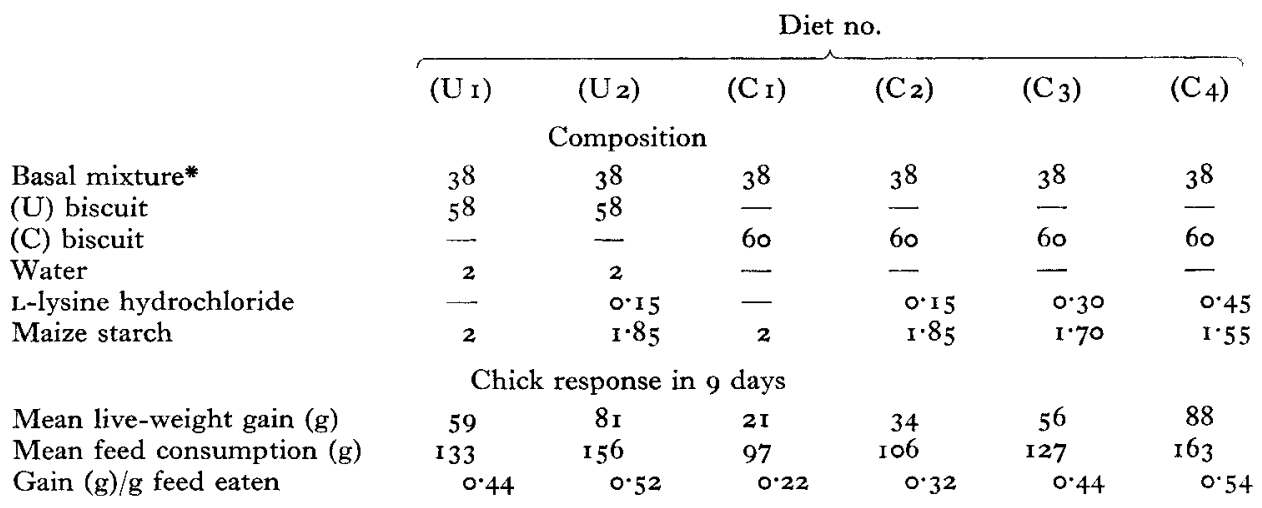

* The basal mixture consisted of sesame-seed meal 25 , zein 3.5 , grass meal 2 , ground oat husk 2 , steamed bone flour 2, ground limestone I, hydrogenated vegetable fat 0.5 , salts 0.5 , DL-methionine 0.25 and starch + vitamins + antibiotic pre-mix, I.25. The pre-mix contributed to each $100 \mathrm{~g}$ of diet: choline chloride 175 , nicotinic acid 5, folic acid 4, calcium pantothenate 3 , $\alpha$-tocopheryl acetate 2 , thiamine hydrochloride, riboflavin and pyridoxine hydrochloride each $\mathrm{x}$, oxytetracycline hydrochloride 0.75 , biotin 0.1 , menadione 0.05 , cyanocobalamin $0.00125 \mathrm{mg}$, together with 880 i.u. vitamin $\mathrm{A}$ and 220 i.u. vitamin $D_{3}$. The salts were made up of sodium chloride fortified with $6 \%$ manganese sulphate and $0.25 \%$ potassium iodide.

Table 2. Estimates of the lysine content of the $(U)$ and $(C)$ biscuits by different laboratory procedures, and of the relative deficit of the $(C)$ biscuits by assay with chicks

\begin{tabular}{|c|c|c|c|}
\hline & $\begin{array}{l}\text { Biscuit } \\
\text { (U) }\end{array}$ & $\begin{array}{l}\text { Biscuit } \\
\text { (C) }\end{array}$ & $\begin{array}{l}\text { Difference } \\
(\mathrm{U})-(\mathrm{C})\end{array}$ \\
\hline $\begin{array}{l}\text { Total lysine }(\mathrm{g} / \mathrm{r} 6 \mathrm{~g} \mathrm{~N}) \text { : } \\
\text { Acid hydrolysis followed } \\
\text { by microbiological assay }\end{array}$ & $4 \cdot 0$ & $4^{\circ} \circ$ & $\circ$ \\
\hline $\begin{array}{l}\text { Available lysine }(\mathrm{g} / \mathrm{I} 6 \mathrm{~g} \mathrm{~N}) \text { : } \\
\text { Procedure } \mathrm{A} \text {, uncorrected } \\
\text { Procedure A, corrected* } \\
\text { Procedure } \mathrm{B}^{*}\end{array}$ & $\begin{array}{l}(3 \cdot 1) \\
3 \cdot 6 \\
3 \cdot 9\end{array}$ & $\begin{array}{l}(I \cdot 9) \\
I \cdot 9 \\
2 \cdot 0\end{array}$ & $\begin{array}{l}(I \cdot 2) \\
I \cdot 7 \\
I \cdot 9\end{array}$ \\
\hline $\begin{array}{l}\text { Relative deficit by chick assay } \\
(\mathrm{g} / \mathrm{l} 6 \mathrm{~g} \mathrm{~N})\end{array}$ & p. 404 . & - & $2 \cdot I$ \\
\hline \multicolumn{4}{|c|}{ RESULTS } \\
\hline Microbiolog & $c h$ & $a \operatorname{ss} a$ & \\
\hline
\end{tabular}

The results of the microbiological assay on acid hydrolysates of the biscuits for 'total lysine' content are given in Table 2. The value found was $4^{\circ} \circ \mathrm{g} / \mathrm{I} 6 \mathrm{~g} \mathrm{~N}$ for each.

The chemical estimation of 'available lysine' by procedure A (without correction) 
gave values of $3^{\cdot} \mathrm{I}$ and $\mathrm{r}^{\cdot} 9 \mathrm{~g} / \mathrm{1} 6 \mathrm{~g} \mathrm{~N}$ for the $(\mathrm{U})$ and $(\mathrm{C})$ biscuits, respectively, indicating an apparent loss of $39 \%$ of the available lysine as a result of introducing the skim-milk powder before the baking. The results are similar to those of Clegg (1960), who found 3.0 and $2.1 \mathrm{~g} / \mathrm{I} 6 \mathrm{~g} \mathrm{~N}$, respectively, for the corresponding preparations in her series of materials. Correction of these values for the interference of histidine increased the difference between them; the proportion of the uncorrected readings attributable to lysine rather than to histidine, as indicated by the extinction ratios at 440 and $400 \mathrm{~m} \mu$ (Carpenter, 1960 ), was $85.5 \%$ for the (U) biscuits and only $73 \%$ for the (C) biscuits. For each, the recovery of added DNPL was approximately $74 \%$, so that the correction factor to allow for it was ' $\times \mathrm{I}^{\top} 35$ '. After applying both types of correction, values of

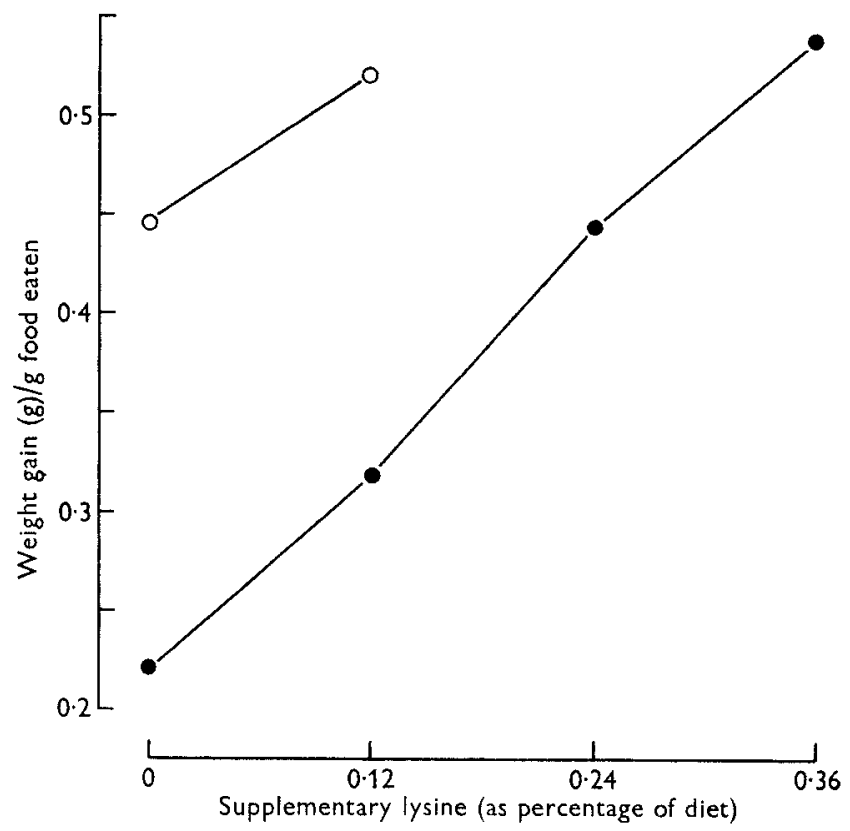

Fig. I. Relationship between amount of lysine added to the diet and efficiency of food conversion of the chicks. $O$, diets containing the (U) biscuits; $O$, diets containing the (C) biscuits.

3.6 and $\mathrm{r} \cdot 9 \mathrm{~g} / \mathrm{r} 6 \mathrm{~g} \mathrm{~N}$ are obtained for the (U) and (C) biscuits, respectively, so that the apparent difference between the two materials was accordingly increased.

Application of procedure B gave the same apparent recovery of $74 \%$ for the internal standard, and the final figures were 3.9 and $2.0 \mathrm{~g} / 16 \mathrm{~g} \mathrm{~N}$.

\section{Biological assay}

The experiment was completed with no losses among the experimental animals. The results are given in Table I, and the relationship between the efficiency of feed conversion and the amount of lysine added to the diets is shown graphically in Fig. I. It will be seen that, as had been expected, both the unsupplemented diets, ( $\mathrm{U}_{\mathrm{I}}$ ) and (C I), supported mors rapid growth when they were supplemented with lysine. 
Statistical analysis of the results indicated that the responses to supplementation of the two diets as set out in Fig. I did not differ significantly in slope; the difference of position between them was equivalent to $0.237 \%$ lysine. Since the biscuits always contributed $I I \cdot I 5 \%$ crude protein to the diets, the difference in lysine activity between the (U) and (C) diets corresponds to a difference of $2 \cdot \mathrm{I} g$ lysine $/ \mathrm{r} 6 \mathrm{~g}$ biscuit $\mathrm{N}$. The analysis of the results also gave \pm 0.021 as a pooled estimate for the standard error of the efficiency of feed conversion on each treatment. This in turn led to an estimate of $\pm 0.21 \mathrm{~g} / \mathrm{1} 6 \mathrm{~g} \mathrm{~N}$ for the standard error of the value for the difference in lysine activity of the two biscuits.

\section{DISCUSSION}

The results confirm the findings of Clegg (1960), first that the particular kind of biscuit meal examined had only about one-half of its lysine units free to react with fluorodinitrobenzene, and, secondly, that if one ingredient of the biscuit, dried skim milk, was added only after cooking, the proportion of the lysine units remaining reactive was considerably greater.

Refinements of the analytical procedure have now given results indicating that the changes caused by cooking in the presence of dried milk were even greater than had previously been found. Moreover, the results of a biological assay with chicks confirm the finding that the availability of the lysine had been lowered fully to the extent shown by the new chemical results.

In contrast to the 'available lysine' content, the total lysine content was apparently no different in the two biscuit meals. This is another instance of the inadequacy of determination of total lysine when applied to processed foodstuffs in general, and in particular to those containing reducing sugars (cf. reviews by Rice $\&$ Beuk, 1953, and Liener, 1958).

\section{Nutritive loss in biscuits}

It is of interest to consider whether or not the finding of such considerable damage in this particular biscuit agrees with the findings of workers who have studied other products of the same type.

Reinius (1955-6) reported his unexpected finding that a mixture designed to represent the Finnish national diet, and baked with the intention of making it palatable for experimental rats, failed to support their growth. The unbaked mixture supported a gain in weight of $2 \mathrm{~g} /$ day, and this result was also given by the baked mixture when it was supplemented with lysine. Approximately $20 \%$ of the dry matter in the mixture came from whole-milk powder, so that the ration had a high lactose content.

Block, Cannon, Wissler, Steffee, Straube, Frazier \& Woolridge (1946) worked with a cake-mix designed originally to give, on baking, a high-protein product providing all the nutrient needs of convalescents. In fact, rats fed on the baked and dried product gained weight at less than one-third the rate of those receiving the raw materials; the depression in weight gain was largely counteracted by supplementing the 'baked' diet with lysine. The only milk product in their mixture was described as 'lactalbumen', which was presumably of low lactose content. The sole ingredient providing an appreciable quantity of a reducing sugar was the $\mathrm{I} \%$ of molasses, 
which may contain $15 \%$ invert sugar (Meade, 195 r). However, the mix included $20 \%$ of sucrose, and also the starch from $5 \mathrm{r} \%$ of wheat flour. Any invertase present in the latter could produce some splitting of the sucrose during preparation of the mix for baking.

Mauron, Mottu \& Egli ( 1960 ) measured, at various stages in the baking process, the 'net protein utilisation' (N.P.U.) for rats of a high-protein biscuit mixture, intended for use in a kwashiorkor area and cooked to different degrees. The N.P.U. of the raw mix was about 70 , and the value was reduced to about half by cooking. It was noticed that a small degree of 'overcooking' of the mixture had a considerable effect on the nutritive value of the proteins. These authors did not investigate the effect of supplementing any of the rat diets with lysine; but from an in vitro study of the release of dialysable amino acids with a combination of enzyme preparations it appeared that the availability of other amino acids in addition to lysine was reduced. With the most damaged biscuits the rate of release of lysine was about $40 \%$ of that for the uncooked mixture, whereas for methionine the corresponding figure was approximately $50 \%$. The only significant source of a reducing sugar was the $6 \%$ of skim-milk powder in the mixture. The milk powder accounted for only a small proportion of the lysine provided by the proteins in the mix; more came from fish meal, groundnut meal and yeast.

It is clear from the findings reviewed above that severe nutritional damage may occur with a variety of procedures for making high-protein biscuits, so that when such materials are being relied on as a source of high-quality protein, checks should be made on the quality of the final product as well as of the individual ingredients. Although milk products containing lactose are particularly dangerous ingredients, impairment has also been found in mixes that do not contain them.

The conditions of bread-making appear to be less damaging (cf. Calhoun, Hepburn $\&$ Bradley, I960); thus, although there is some nutritive loss during baking, the addition of skim-milk powders to the dough nevertheless results in a considerable net increase in the protein value of the product (Sabiston \& Kennedy, 1957; Morrison \& Campbell, I960). There is considerably more damage to crust than to crumb, but crust forms only a small proportion of the total weight of a loaf (see Morgan, I93 I Hutchinson, Moran \& Pace, 1960). The high moisture content of crumb, as compared with crust or biscuits, may be part of the explanation, since above a certain point the binding of protein and carbohydrate is inhibited by increased relative humidity (Lea \& Hannan, 1949; Renner, Clandinin \& Robblee, 1953).

\section{Chemical estimations of 'available lysine' in vegetable materials}

Bensabat, Frampton, Allen \& Hill (1958) demonstrated that the reactivity of the $\epsilon-\mathrm{NH}_{2}$ lysine groups of groundnuts was reduced after severe processing, and recently Mauron \& Bujard (1960) have found that such changes are correlated with changes in the nutritional value for rats of groundnut proteins. Now in the work presented here we have shown that the analytical method had correctly indicated a severe reduction in the biologically available lysine in biscuits containing both vegetable and animal ingredients. There is, however, insufficient information to justify generalizations about 
the nutritional significance of the values for 'available lysine' for vegetable material, as obtained by measuring their reactivity with fluorodinitrobenzene.

Handwerck, Bujard \& Mauron ( 1960 ) have discovered that the conditions of the chemical procedure partly protect DNPL from the destructive effect of acid hydrolysis in the presence of sugars. The protection is less effective with starch, and, in this study, recovery of added DNPL was only $74 \%$, compared with the mean recovery of $92 \%$ obtained with animal products essentially free of carbohydrate (Carpenter, r960). Further, we cannot be certain that $\epsilon$-DNPL units have the same degree of stability when free as when held in peptide linkages. It may also be that some linkages through the $\epsilon-\mathrm{NH}_{2}$ groups to be found in processed vegetable foods can be broken in the alimentary tract or that unrecognized interfering compounds will be encountered.

Nevertheless, from the information available so far it seems that the fluorodinitrobenzene procedure may prove a useful and simple tool for the screening of vegetable food preparations valued as sources of high-quality protein. There is a need for modification of the procedure with foods rich in carbohydrates, so as to reduce their destructive effect on DNPL during acid hydrolysis.

\section{SUMMARY}

I. A biscuit meal (C) was prepared from a high-protein mixture, which included $41 \%$ of groundnuts and $15 \%$ of skim-milk powder. A second meal (U) was prepared in the same way except that the milk powder was not added until after the other ingredients had been baked and milled.

2. As previously reported (Clegg, I960), the inclusion of milk powder during the baking of such biscuits resulted in a large proportion of the $\epsilon-\mathrm{NH}_{2}$ groups of the lysine units in the final meal becoming unavailable for reaction with fluorodinitrobenzene.

3. After correction for losses during hydrolysis and interference from histidine the reactive lysine amounted to $3.6 \mathrm{~g} / \mathrm{1} 6 \mathrm{~g} \mathrm{~N}$ (or $3.9 \mathrm{~g}$ by a slightly different procedure) in the (U) biscuits, and to $\mathrm{I} \cdot 9$ (or $2 \cdot 0$ ) $\mathrm{g}$ in the (C) biscuits.

4. In a biological assay with young chicks, the live-weight gain/g food eaten showed that $2 \cdot \mathrm{I} g( \pm 0 \cdot 2 \mathrm{I})$ more available lysine was contributed from $\mathrm{I} 6 \mathrm{~g} \mathrm{~N}$ of the (U) biscuit meal than from $16 \mathrm{~g} \mathrm{~N}$ of the (C) biscuit meal.

5. The 'total lysine' content of acid hydrolysates of the two biscuit meals was $4^{\circ} \circ \mathrm{g} / \mathrm{I} 6 \mathrm{~g} \mathrm{~N}$ for each, as judged by a conventional assay with Leuconostoc mesenteroides.

6. It is concluded that the fluorodinitrobenzene procedure for estimating 'available lysine' has been useful for detecting damage to this type of material, but that more work is needed before it can be applied to vegetable materials in general.

One of us (B.E.M.) is indebted to the Royal Society and the Nuffield Foundation for a Commonwealth Bursary held during the course of this work. 


\section{REFERENCES}

Bensabat, L., Frampton, V. L., Allen, L. E. \& Hill, R. A. (1958). F. agric. Fd Chem. 6, 778.

Block, R. J., Cannon, P. R., Wissler, R. W., Steffee, C. H. Jr., Straube, R. L., Frazier, L. E. \& Woolridge, R. L. (1946). Arch. Biochem. ro, 295.

Bruno, D. \& Carpenter, K. J. (1957). Biochem. F. 67, г3 $P$.

Calhoun, W. K., Hepburn, F. N. \& Bradley, W. B. (I960). F. Nutr. 7r, 337.

Carpenter, K. J. (1960). Biochem. F. 77, 604.

Carpenter, K. J., Jones, W. L. \& Mason, E. L. (1959). Biochem. F. 73, i 1 P.

Clegg, K. M. (1960). Brit. F. Nutr. I4, 325.

Handwerck, V., Bujard, E. \& Mauron, J. (1960). Biochem. F. 76, 54 P.

Hutchinson, J. B., Moran, T. \& Pace, J. (1960). F. Sci. Fd Agric. Ix, 576.

Lea, C. H. \& Hannan, R. S. (1949). Biochem. Biophys. Acta, 3, 313.

Liener, I. E. (1958). Processed Plant Protein Feedstuffs, p. 79. [A. A. Altschul, editor.] New York: Academic Press Inc.

Mauron, J. \& Bujard, E. (1960). Ann. Nutr., Paris, 14, 29 I.

Mauron, J., Mottu, F. \& Egli, R. H. (1960). Ann. Nutr., Paris, 14, 135.

Meade, G. P. (195 I). Food and Food Products, 2nd ed., Vol. 3, p. 2129. [M. B. Jacobs, editor.] New York and London: Interscience Publishers Inc.

Morgan, A. F. (r93I). F. biol. Chem. 9o, 77 I.

Morrison, A. B. \& Campbell, J. A. (1960). Canad. 7. Biochem. Physiol. 38, 467.

Reinius, L. R. (1955-6). Acta physiol. scand. 35, 265.

Renner, R., Clandinin, D. R. \& Robblee, A. R. (r953). Poult. Sci. 32, 582.

Rice, E. E. \& Beuk, J. F. (1953). Advanc. Food Res. 4, 233.

Sabiston, A. R. \& Kennedy, B. M. (1957). Cereal Chem. 34, 94. 